\title{
Presence of ascites in bullfrog breeders reared and kept on a frog farm
}

[Presença de ascite em reprodutores de rã-touro criados e mantidos em ranário]

\section{J.T. Seixas Filho ${ }^{1}$, A.C. Santana ${ }^{1}$, A.C.P.F. Martins ${ }^{2}$, E.F.M. Mesquita ${ }^{3}$, S.C.R.P. Mello ${ }^{1,4}$, M. Hipolito ${ }^{2}$}

${ }^{1}$ Centro Universitário Augusto Motta - Rio de Janeiro, RJ

${ }^{2}$ Instituto Biológico de São Paulo - São Paulo, SP

${ }^{3}$ Universidade Federal Fluminense - Niterói, RJ

${ }^{4}$ Fundação Instituto de Pesca do Estado do Rio de Janeiro - Guaratiba, RJ

\begin{abstract}
Ascites is a pathology characterized by the extravasation of fluid from blood vessels and its accumulation in the abdominal cavity, caused by several associated factors. In this paper, we report the occurrence of this syndrome in breeding male and female Bullfrogs fed a commercial fish feed with $40 \%$ crude protein. Liver malformation was already observed due to lack of protein deposition in adult animals from the same spawning. The culture of ascitic fluid showed absence of bacterial growth. Kidney histopathology showed, in both sexes, a large number of tubular structures with strongly eosinophilic hyaline material suggesting colloid growth in both the cortical region and spinal cord. The analysis also revealed granulomas in various stages of development, many showing central necrotic material. The kidneys, glomerular, were mostly hypoplastic, with enlarged Bowman space, and many were hyalinized or hemorrhagic; the parenchyma showed dystrophic calcification, and many tubules containing fibrinoid material. The liver displayed a large amount of melanomacrophages in the parenchyma and foci of mono-lymphocytic hepatitis and marked cytoplasmic rarefaction, as well as several hepatocytes with pyknotic nuclei and necrotic cells and dissociation of the hepatic trabeculae. Ascites may be caused by the lesions observed in these organs.
\end{abstract}

Keywords: captive breeding, feeding, histopathology, metabolic disease, Lithobates catesbeianus

\section{RESUMO}

A ascite é uma condição patológica que se caracteriza pelo extravasamento do líquido dos vasos sanguíneos e por seu acúmulo na cavidade abdominal provocado por uma somatória de fatores. É considerada uma síndrome de caráter multifatorial e, uma vez desencadeado o processo ascítico, esse se torna, na maioria dos casos, irreversivel. O objetivo deste trabalho foi relatar a ocorrência dessa síndrome em machos e fêmeas reprodutores de rã-touro (Lithobates catesbeianus), alimentados com ração comercial para peixes, com 40\% de proteína bruta, durante três anos e já sendo observada má formação de figado, por falta de deposição proteica, em animais adultos da mesma desova. A cultura do líquido ascítico demonstrou ausência de crescimento bacteriano. Na histopatologia, observou-se, para ambos os sexos, nos rins, grande número de estruturas tubulares com material fortemente eosinofílico e hialino, sugerindo coloide, tanto na região cortical como na medular. Visualizaram-se também granulomas em vários estágios de desenvolvimento, muitos apresentando material necrótico central. Ainda se pôde observar que os aparelhos renais, os glomérulos, em sua maioria, estavam hipoplásicos e com aumento do espaço de Bowman, e muitos hialinizados ou hemorrágicos; além de calcificação distrófica no parênquima e nos dos túbulos, havia material fibrinoide no seu interior. No fígado, pôde-se ver grande quantidade de melanomacrófagos no parênquima e focos de hepatite monolinfocitária e acentuada rarefação citoplasmática, assim como vários hepatócitos com núcleo em picnose e células em necrose e dissociação das trabéculas hepáticas. A causa da ascite pode ser devido às lesões observadas nesses órgãos.

Palavras-chave: criação em cativeiro, alimentação, histopatologia, doença metabólica, Lithobates catesbeianus

Recebido em 14 de novembro de 2018

Aceito em 25 de janeiro de 2019

E-mail: seixasfilho@yahoo.com.br 


\section{INTRODUCTION}

Ascites may result from cardiovascular, hepatic, or renal diseases (Bertelsen and Crawshaw, 2003; Gentz, 2007; Pessier, 2009), and it is a common finding in captive wild amphibians (Pessier, 2009). Hipolito et al. (2003) reported the viral presence in tadpoles and metamorphosed bullfrogs that had ascites and edema associated secondarily with nutrition. Speare and O'shea (1989) commented on the isolation of an unidentified virus of Australian wild frog Limnodynastes ornatus causing anasarca, ascites, and cutaneous hemorrhage in tadpoles. Wolf et al. (1968) and Granoff (1969) presented cases of TEV (tadpole edema virus) isolated from tadpoles with the disease and from normal adult Bullfrogs.

Secondary contaminants such as bacteria, fungi, and viruses may be associated with ascites, further compromising the health of the animal; hence the importance of examining this coelomic fluid (Glorioso et al., 1974; Amborski et al., 1983; Bertelsen and Crawshaw, 2003; Greer et al., 2005; Pasteris et al., 2006; Gentz, 2007; Mazzoni et al., 2012). Diseases with high mortality rates, characterized clinically by edema and ascites, have repeatedly been observed in farmed Bullfrog tadpoles. Knowledge of these diseases is scarce (Pessier, 2009), which makes it necessary to determine the root causes involved so that the appropriate prophylactic and therapeutic measures can be suggested (Hipolito, 2004).

Seixas Filho et al. (2008) observed cytoplasmic rarefaction in hepatocytes of Bullfrogs in tadpole and imago stages and found that this change was still present in the livers of adults that formed the breeding stock (Seixas Filho et al., 2010). The authors concluded that this fact was related to the low quality of the protein from the commercial fish feed traditionally used in frog farms in Rio de Janeiro (Brazil), but with little or no presence of ascites.

With the advancement of knowledge about management and nutrition, frog farming has become a super-intensive activity, with high population densities and strict dependence on balanced foods. However, intensive farming methods have facilitated the emergence of diseases that pose a threat to the technical and economic viability of farms of aquatic organisms (Rottmann et al., 1992; Bondad-Reantaso et al., 2005; Teixeira et al., 2014).

These cases may or may not be accompanied by nervous symptoms, and, at times, sudden deaths. It is common for the various medical conditions that compose the ascites syndrome to occur in one single outbreak (Antonucci et al., 2014). At present, frog farming in Brazil is an alternative agro-industrial activity, especially for producers with limited available space, as it can be profitable in small areas (Dias et al., 2008). Considering the above-stated scenario, the objective of the study was to describe histopathological alterations observed in various organs of Bullfrogs with ascites, helping to fill the gap of lacking information on this subject, involving these animals.

\section{MATERIALS AND METHODS}

The study was conducted at the Laboratories of Biology Research at the Augusto Motta University Center (UNISUAM) and Rio de Janeiro State Fishing Foundation Institute (FIPERJ), located in Rio de Janeiro, Rio de Janeiro, Brazil, where Bullfrog specimens were necropsied and the ascitic fluid was removed. The animals were transported to the Alcântara Laboratory, located in Niterói, Rio de Janeiro, Brazil. Histopathological analysis was performed at the Inter-institutional Laboratory of Health in Aquaculture, at the São Paulo Biological Institute.

The experiment included seven specimens of adult Bullfrogs aged three years, which belonged to the breeding stock of the experimental frog farm at FIPERJ. These animals were part of the $\mathrm{F}_{2}$ population obtained from the offspring of frogs originating from the cross between specimens from the states of São Paulo and Minas Gerais, Brazil. The specimens included four females weighing 784.60, 976.80, 743.70, and $744.00 \mathrm{~g}$ and three males weighing 720.20 , 750.00 , and $1,087.10 \mathrm{~g}$, which were weighed after removal of abdominal fluid that caused a marked engorgement of that body region. The animals collected from the breeding stock were anesthetized by hypothermia with benzocaine and sacrificed by spinal cord section, as recommended by IACUC (Fish..., 2018), 
according CEUA-FIPERJ number 0006/2017. Subsequently, the spinal cord was removed.

After the sacrifice, the specimens were transferred to a laminar flow hood, avoiding contamination of this material. Afterwards, the abdomen was sterilized with cotton moistened in iodized alcohol and punctured with a $5 \mathrm{~mL}$ syringe with a $20 \times 5.5 \mathrm{~mm}$ needle inserted in the lateral-medial region of the abdomen. The harvested abdominal fluid was transferred to a dry sterile tube and immediately transported in a closed container under refrigeration for microbiological analysis.

To evaluate the pathological lesions the abdominal fluid accumulation would be causing in the animals, they were necropsied in dorsal decumbency, making a posterior-anterior ventral incision with fine-point surgical scissors and exposing their viscera. Liver and kidneys were separated with care using forceps to isolate and not deform the organs. Collected livers and kidney were fixed in 10\% calcium carbonatebuffered formaldehyde. For the histological procedure, the organs were dried, cleared, paraffin-embedded, and cut into $5 \mu \mathrm{m}$ portions, stained with hematoxylin-eosin (HE), and observed in a common optical microscope by direct transillumination (Seixas Filho et al., 2013). For the possible bacteriological diagnosis, ascitic fluid was cultured in specific medium using DADE/BERHING MICROSCAN automated robotic system, following Sato et al. (2003).

\section{RESULTS}

Macroscopically, there were marked changes in the organs, especially in the kidneys and liver, which were edematous and with increased volume. The liver showed an alteration in color, more darkened or paler than normal, and some darkened and more friable areas resembling necrosis, probably due to pressure from fluid accumulation. Some specimens had the heart and lungs also edematous. Kidneys had a much darker red color than normally observed. Some organs showed, externally, a whitish globular structure similar to nodules.

Histological examination revealed many tubular structures with highly eosinophilic hyaline material, suggesting colloid growth in the kidneys of the three males. Numerous granulomas were present in various stages of development, many having central necrotic material. The kidneys, glomerular, were mostly hypoplastic and showed enlarged Bowman space, and many were hyalinized. We also observed dystrophic calcification in the parenchyma as well as hemorrhagic areas and sclerotic blood vessels. Many of the tubules presented fibrinoid material in their interior, and some of the tubular cells contained brown granular pigment (Figure 1). The liver displayed many parenchymal melanomacrophages and foci of mono-lymphocytic hepatitis, besides marked cytoplasmic rarefaction and several pyknotic nuclei of hepatocytes and necrotic cells (Figure 2 ). The tests performed in the kidneys (Figures. $3,4,5,6$ ) and liver (Figure 7) of the four females also showed marked changes in these organs, similarly to males. Bacteriological examination of the ascitic fluid showed negative results.

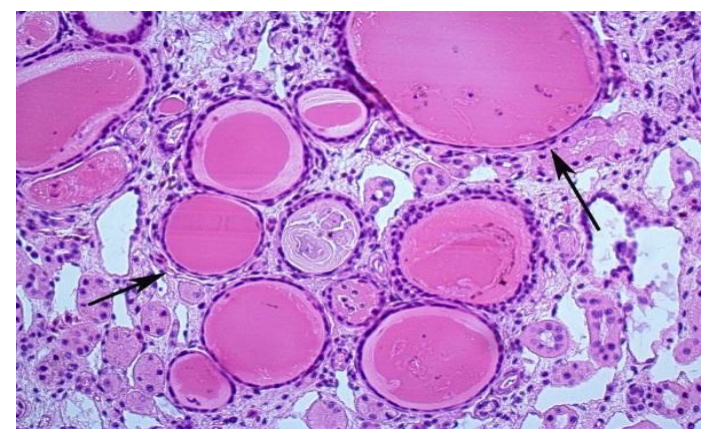

Figure 1. Photomicrograph of the kidney of a breeding male Bullfrog fed commercial fish feed with $40 \% \mathrm{CP}$. Presence of hyaline corpuscles (arrows). HE staining, 200x.

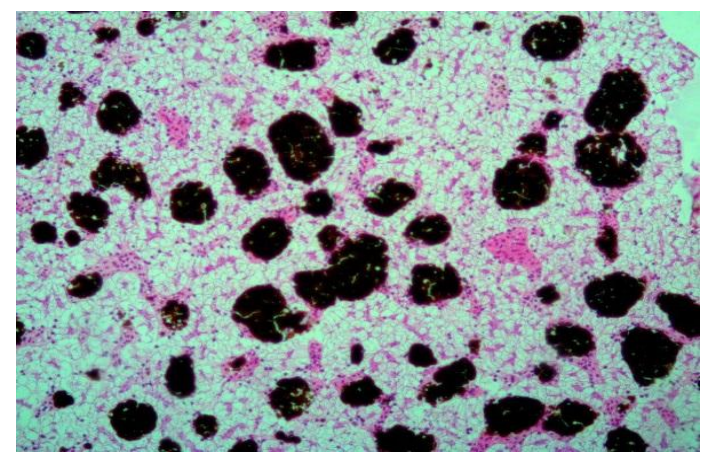

Figure 2. Photomicrograph of the liver of a female Bullfrog fed commercial fish feed with $40 \%$ CP. Presence of melanomacrophages (dark cells) and cytoplasmic rarefaction. HE staining, $100 \mathrm{X}$. 


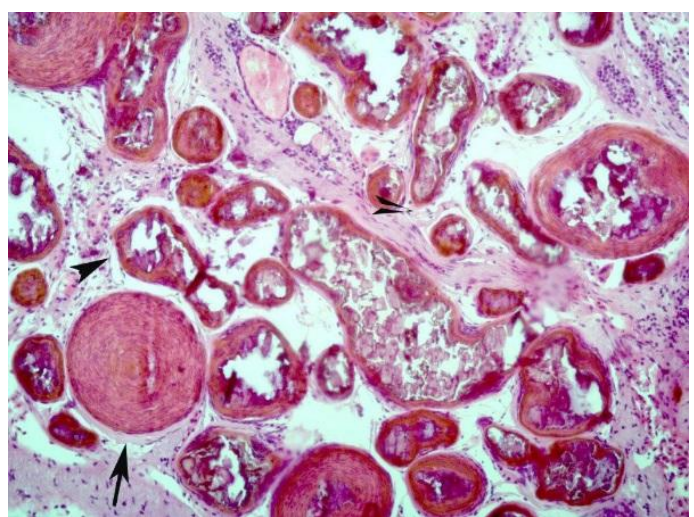

Figure 3. Photomicrograph of the kidney of a female bullfrog fed commercial fish feed with $40 \%$ CP. Presence of dystrophic calcification (short arrow) and granuloma (long arrow). HE staining, 100X.

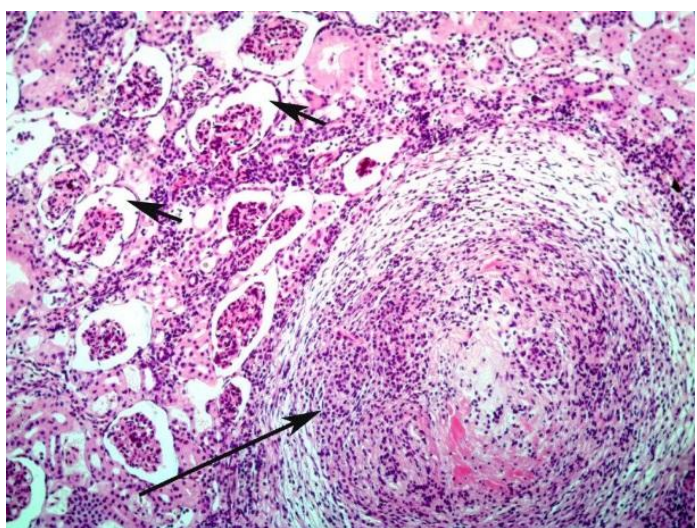

Figure 4. Photomicrograph of the kidney. Note the enlarged Bowman space (short arrow) and granuloma (long arrow). HE staining, 100X.

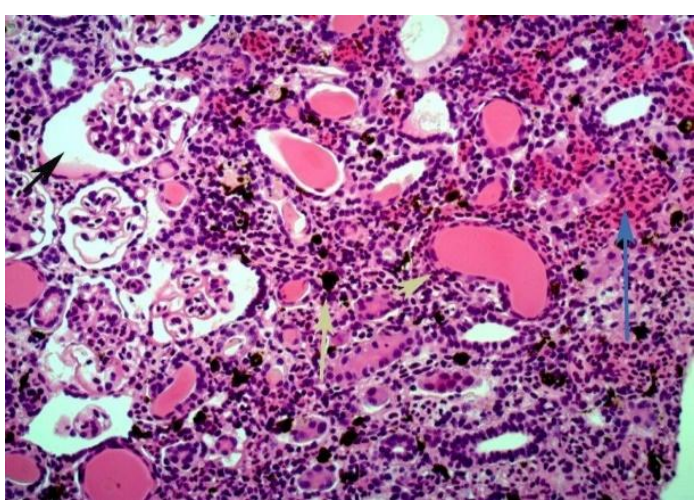

Figure 5. Photomicrograph of the kidney. Presence of hypotrophic glomeruli in degeneration (short arrow), hemorrhagic areas (long blue arrow), hyaline corpuscles (short yellow arrow), and melanomacrophages (long yellow arrow). HE staining, 200X.

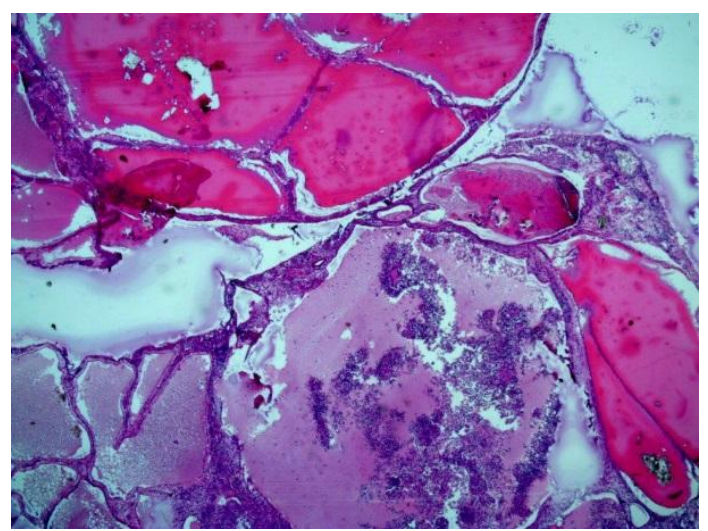

Figure 6. Photomicrograph of kidney with monolymphocytic infiltration and dead cells (bottom). HE staining, 250X.

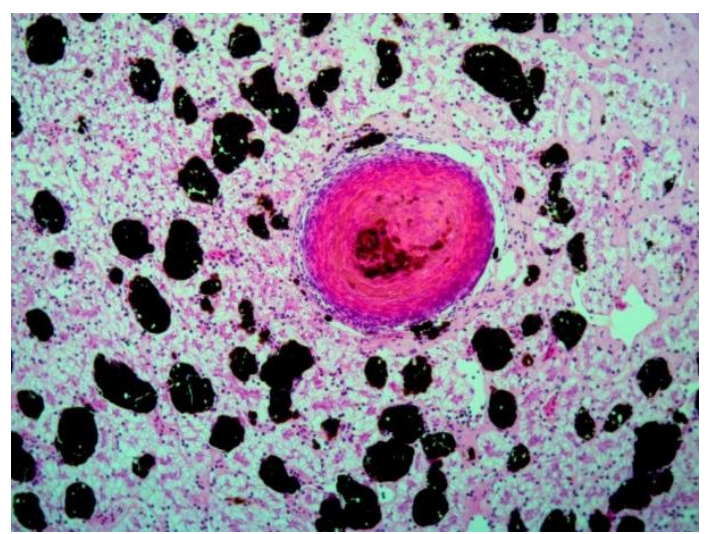

Figure 7. Photomicrograph of the liver of a female Bullfrog fed commercial fish feed with $40 \%$ CP. Presence of melanomacrophages (dark cells) and granuloma (center). HE staining, $100 \mathrm{X}$.

\section{DISCUSSION}

These morphological histopathological lesions observed with the presence of melanomacrophages, rarefaction of hepatic cells, and granulomas in the liver, in addition to hyaline tubular structures/fibrin, granulomas/necrosis/abscesses, hyaline and hyperplastic glomeruli, dystrophic calcification, tubular nephritis, and hemorrhage/blood clotting in the kidney, seen in most animals, are in agreement with other experiments such as those of Pessier (2009); Vannevel (2006). These authors mentioned that color and structural changes were also observed, as in the present case. 
Our findings may be indicating chronic, recurrent lesions, caused probably, in this case, by a nutritional process; this situation was commented by Cecil (2006). The presence of this rarefaction of liver cells may be due to a proteinmineral deficiency.

These hepatic lesions can interfere with the metabolism of these animals, resulting in protein metabolism disorders and consequently renal lesions such as hyaline structures and hypoplastic glomeruli and their degeneration. This can cause necrosis and the observed dystrophic calcifications, as stated by Vannevel (2006). These lesions are associated mostly with what is usually seen in cases of nutritional deficit resulting from poor feed quality or poor use of the feed ingredients, in which case Bullfrogs, a carnivorous species, are forced to feed on vegetable products, compromising their dietary protein use (Hipolito, 2004; Seixas Filho et al., 2008, 2010.).

The large number of melanomacrophages observed suggests greater damage to the liver parenchyma, probably due to toxicity of the environment. Other researchers have also reported this increased presence of melanomacrophages, e.g., Pessier (2009); Vannevel (2006). The occurrence of granulomas, tubular nephritis, and lymphocytic hepatitis is associated with the presence of some attacker microbial agent such as bacteria. Presence of mycobacteria is more likely in the granulomas, as also commented by Vannevel (2006). The observed lesions, which significantly compromised the physiology of these organs, suggest the participation of these alterations in the pathophysiology of ascites, as also mentioned by Cecil (2006); Vannevel (2006).

Because it seems to bean aggressive chronic situation, probably caused by a process resulting from poor nutritional quality that led to serious damage to liver and kidneys, and because these were adult, breeding animals with a long lifespan, these changes had been present for some time. And the fact that they are under permanent care in an ideal situation of hygiene, housing density, and management lessens the impact of the attacks, providing greater longevity. In non-ideal management situations, their deaths would presumably occur earlier. A more in-depth discussion is a difficult task, given the little available information on ascites and its association with histopathological lesions.

\section{CONCLUSION}

These unprecedented findings imply that ascites in Bullfrog specimens is associated with hepatic and renal lesions, and these lesions are in turn related to the use of an inappropriate, imbalanced fish feed for three years that led to poor nutritional quality. Consequently, metabolic processes in these animals were negatively affected.

\section{REFERENCES}

AMBORSKI, R.L.; SNIDER, T.G.; THUNE, R.L.; CULLEY, D.D. A nonhemolytic, group B Streptococcus infection of cultured bullfrogs, Rana catesbeiana, in Brazil. J. Wildl. Dis., v.19, p.180-184, 1983.

ANTONUCCI, A.M.M.H.B.; CATROXO, M.; HIPOLITO, R.M. et al. Tracking viral particles in intestinal contents of the American bullfrog, Lithobates catesbeianus, by Transmission Electron Microscopy. Arq. Bras. Med. Vet. Zootec., v.66, p.321-328, 2014.

BERTELSEN, M.; CRAWSHAW, G. 5-minute guide to amphibian disease. Exotic DVM, 2003. Available in: <http://www.amphibianark.org/wpcontent/uploads/2018/07/> Accessed in: 10 Dec. 2017.

BONDAD-REANTASO. M.G.; SUBASINGHE, R.P.; ARTHUR, J.R. et al. Disease and health management in Asian aquaculture. Vet. Parasiltol., v.132, p.249-272, 2005.

CECIL, T. R. Amphibian renal disease. Vet. Clin. Exot. Anim. Pract., v.9, p.174-188, 2006.

DIAS, D.C.; STÉFANI, M.V.; FERREIRA, C.M.; FRANÇA, F.M. Use of probiotics in the ration of bullfrog (Rana catesbeiana): productive performance. Arch. Zootec., v.57, p.449-455, 2008.

FISH and Amphibian Euthanasia (CARE 306.02revision). Institutional Animal Care and use Committee - Cornell University, 2018. Available in: $<$ https://ras.research.coenell.edu/care/docume nts/ACUPs/ACUP306.pdf $>$. Accessed in: 11 Oct. 2018. 
GENTZ, E.J. Medicine and surgery of amphibians. ILAR J., v.48, p.255-259, 2007.

GLORIOSO, J.C.; AMBORSKI, R.L.; AMBORSKI, G.F.; CULLEY, D.D. Microbiological studies on septicaemic bullfrogs (Rana catesbiana). Am. J. Vet Res., v.35, p.12411245, 1974.

GRANOFF, A. Viruses of amphibian. Curr. Top. Microbiol. Immunol., v.50, p.107-137, 1969.

GREER, A.; BERRILL, M.; WILSON, P. Five amphibian mortality events associated with ranavirus infection in south central Ontario, Canada. Dis. Aquat. Organ., v.67, p.9-14, 2005.

HIPOLITO, M. Manejo sanitário no cultivo de rã. In: RANZANI-PAIVA, M.J.T.; TAKEMOTO, R.M.; LIZAMA, M.L.A.P.L. (Ed.). Sanidade de organismos aquáticos. São Paulo: Varela, 2004. p.333-353.

HIPOLITO, M.; CATROXO M.H.B.; CURI, N.A. et al. Detection by transmission electron microscope of herpes, toga and paramixo-like particles virus in bullfrog (Rana catesbeiana shaw, 1802) from commercial froggeries. first observations in Brazil. Arq. Inst. Biol., v.70, 2003. CD-Rom.

MAZZONI, R.A.; MESQUITA, A.J.M.; FLEURY, L.F.; MESQUITA, S.P. Septicemia in pre-metamorphic farmed tadpoles. Cienc. Anim. Bras., v.13, p.1-6, 2012.

PASTERIS, S.; BUHLER, M.; NADERMACIAS, M. Microbiological and histological studies of farmed-bullfrog (Rana catesbeiana) tissues displaying redleg syndrome. Aquaculture, v.251, p.11-18, 2006.

PESSIER, A.P. Edematous frogs, urinary tract disease, and disorders of fluid balance in amphibians. J. Exot. Pet. Med., v.18, p.4-13, 2009.

ROTTMANN, R.; FRANCIS-FLOYD, R.; DURBOROW, R. The role of stress in fish disease. South Regional Aquaculture Center Publication, 1992. Available in: <http://aquanic.org/publicat/usda_rac/efs/srac/47 4fs.pdf>. Accessed in: 10 Aug. 2017.
SATO, A.F.; SVIDZINSKI, A.S.; CONSOLARO, M.E.; BOER, C.G. Urinary nitrite and urinary-tract infection by grampositive cocci. J. Bras. Patol. Med. Lab., v.41, p.397-404, 2003.

SEIXAS FILHO, J.T.; HIPÓLITO, M. et al. Liver histopathological changes in breeding bullfrogs. Acta Sci. Biol. Sci., v.35, p.402-465, 2013.

SEIXAS FILHO, J.T.; HIPOLITO, M.; CARVALHO, V.F. et al. Histopathological alterations in bullfrog tadpoles fed commercial diets with three levels of crude protein. Rev. Bras. Zootec., v.37, p.2085-2089, 2008.

SEIXAS FILHO, J.T.; NAVARRO R.D.; SILVA L.N. et al. Bullfrog tadpoles performance fed commercial ration with different crude protein levels. Rev. Bras. Cienc. Agrar., v.5, p.428-433, 2010.

SPEARE, R.; O'SHEA, P. The marine toad, Bufo marinus. In: AUSTRALIA AND THE SEARCH FOR A KILLER DISEASE. ANNUAL MEETING OF THE AMERICAM ASSOCIATION OF THE ZOOLOGY VETERINARY, 1989, North Carolina. Proceedings... North Carolina, AAZ, 1989, p.166-172.

TEIXEIRA, P.C.; FRANÇA, F.M.; ROCHA, G.C. et al. Is hypoxia a stressor to American bullfrog tadpoles? Pesqui. Vet. Bras., v.34, p.5055, 2014.

VANNEVEL, J.V. Glomerulonephritis and anasarca in a colony of frogs. Vet. Clin. Exot. Anim. Pract., v.9, p.609-616, 2006.

WOLF, K.; BULLOCK, G.L.; DUNBAR, C.E.; QUIMBY, M.C. Tadpole edema virus: a viscerotropic pathogen for anuran amphibians. $J$. Infect. Dis., v.118, p.253-262, 1968. 